This article was downloaded by: [University of Manchester]

On: 27 October 2008

Access details: Access Details: [subscription number 789759986]

Publisher Routledge

Informa Ltd Registered in England and Wales Registered Number: 1072954 Registered office: Mortimer House, 37-41 Mortimer Street, London W1T 3JH, UK

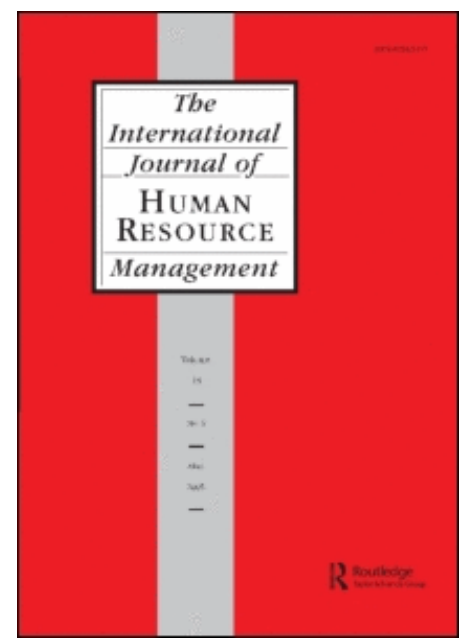

The International Journal of Human Resource Management

Publication details, including instructions for authors and subscription information: http://www.informaworld.com/smpp/title content=t713702518

Varieties and variability of employee relations approaches in US subsidiaries: country-of-origin effects and the level and type of industry internationalisation Heinz-Josef Tüselmann a; Matthew M. C. Allen a; Stuart Barrett a; Frank McDonald b

a Centre for International Business and Innovation, Manchester Metropolitan University Business School, Manchester, UK ${ }^{\text {b }}$ Machester Business School, University of Manchester, Manchester, UK

Online Publication Date: 01 September 2008

To cite this Article Tüselmann, Heinz-Josef, Allen, Matthew M. C., Barrett, Stuart and McDonald, Frank(2008)'Varieties and variability of employee relations approaches in US subsidiaries: country-of-origin effects and the level and type of industry internationalisation', The International Journal of Human Resource Management, 19:9,1622 - 1635

To link to this Article: DOI: $10.1080 / 09585190802295041$

URL: http://dx.doi.org/10.1080/09585190802295041

PLEASE SCROLL DOWN FOR ARTICLE

Full terms and conditions of use: http://www.informaworld.com/terms-and-conditions-of-access.pdf

This article may be used for research, teaching and private study purposes. Any substantial or systematic reproduction, re-distribution, re-selling, loan or sub-licensing, systematic supply or distribution in any form to anyone is expressly forbidden.

The publisher does not give any warranty express or implied or make any representation that the contents will be complete or accurate or up to date. The accuracy of any instructions, formulae and drug doses should be independently verified with primary sources. The publisher shall not be liable for any loss, actions, claims, proceedings, demand or costs or damages whatsoever or howsoever caused arising directly or indirectly in connection with or arising out of the use of this material. 


\title{
Varieties and variability of employee relations approaches in US subsidiaries: country-of-origin effects and the level and type of industry internationalisation
}

\author{
Heinz-Josef Tüselmann ${ }^{\mathrm{a} *}$, Matthew M.C. Allen ${ }^{\mathrm{b}}$, Stuart Barrett ${ }^{\mathrm{a}}$ and Frank McDonald ${ }^{\mathrm{c}}$ \\ ${ }^{a}$ Centre for International Business and Innovation, Manchester Metropolitan University Business School, \\ Manchester, UK; ${ }^{b}$ Machester Business School, University of Manchester, Manchester, UK; ${ }^{c}$ School of \\ Management, University of Bradford, Bradford, UK
}

\begin{abstract}
This article investigates the relative importance and variability of the country-of-origin effect in employee relations approaches of US subsidiaries within the context of diversity of employee relations patterns in home- and host-country business systems and the influence of important industry forces. It is based on a representative survey of US subsidiaries and indigenous firms in the UK. The cross-sectional comparison with indigenous UK firms confirmed a distinct US country-of-origin imprint in employee relations patterns in US subsidiaries. However, the magnitude of such an effect cautions against assumptions of popular stereotypes and reflects, inter alia, the diversity of employee relations approaches among US parent companies as well as developments in the UK industrial relations landscape over the last decades. The intra-US analysis revealed the importance of both the level and type of industry internationalisation in shaping the strength and nature of the country-of-origin influence. On the basis of the findings, the article highlights lessons to be learned for the study of cross-border policy-transfer issues in MNCs.
\end{abstract}

Keywords: country-of-origin; employee relations; industry internationalisation; multinationals

\section{Introduction}

In the area of human resource management (HRM) and employee relations (ER), the country-oforigin effect on ER practices and approaches in overseas subsidiaries of multinational companies (MNCs) forms an important strand of research. The ER approaches in US MNCs' international operations are of particular interest for three main reasons. First, nearly one-quarter of global outward foreign direct investment (FDI) stocks originates from US MNCs (UNCTAD 2006). Second, the competitive strengths that have been associated with US MNCs have meant that the business and management models of such companies have frequently been ascribed the status of global best practice (Scullion and Starkey 2000). Third, US-owned firms have played a flagship role in introducing ER and HRM innovations into the industrial relations (IR) settings of host countries (Ferner 2003).

Many of the recent lines of inquiry into the relative importance of the country-of-origin effect in US subsidiaries, and foreign-owned subsidiaries in general, focus on the way HRM/ER outcomes are shaped by the interplay between the institutional environments of the home- and host-country business systems (BS), and by globalisation pressures pushing for the international integration of MNC activity and approaches on a best-practice template (Ferner, Almond, Clark, Colling and Holden 2004; Edwards and Kuruvilla 2005). The latter aspect draws attention to the

\footnotetext{
*Corresponding author. Email: h.tuselman@mmu.ac.uk
} 
differential impact of industry characteristics on the international ER approaches of MNCs. First, competitive pressures for cross-border integration do not constitute a universal force, but are, to a considerable extent, contingent upon the nature of the industry, in particular upon the degree of industry globalisation (Marginson, Armstrong, Edward and Purcell 1995). Second, even among industries that are highly internationalised, the notion of best practice is not universal, but has a configuration that is industry specific. This reflects, inter alia, differences between highly internationalised industries in areas such as labour markets, human-capital, knowledge and technology intensity (Dunning 2000; Nachum and Zaher 2005). Thus, both the level and type of industry internationalisation can be expected to impact upon the cross-border ER approaches of MNCs.

A number of recent case studies reveal a complex interaction between home-country, host-country and industry-specific influences on the ER patterns in US-owned subsidiaries as well as those of other MNCs (Ferner, Quintanilla and Varul 2001; Geppert, Matten and Williams 2003; Clark and Almond 2004). None of the existing quantitative studies explicitly investigates the variability of the strength and nature of the country-of-origin effect across different industry subsets - in particular, its potential links to the level and type of industry internationalisation. Although existing comparative studies (e.g. Guest and Hoque 1996; Walsh 2001; Schmitt and Sadowski 2003) generally include broad industry dummies in the regression equations, they only note the average nationality effect and, thus, stop the analysis too early. Furthermore, the current body of quantitative studies investigating cross-border ER transfer issues exhibits a number of limitations that make it difficult to arrive at general conclusions (for a more detailed treatment see, e.g. Harzing and Sorge 2003; Tüselmann, McDonald and Thorpe 2006). These relate, inter alia, to sample idiosyncrasies due to small sample sizes, low response rates, insufficient representativeness, and heavily skewed nationality groups that lead to few observations for particular nationality groups. This latter characteristic lowers the reliability of the estimations. Nearly all studies deal with individual practices in isolation rather than assessing encompassing ER approaches. There is also generally little evidence to suggest that crucial pre-estimation tests have been performed prior to the regression analyses being conducted. Furthermore, it is often unclear whether the results have been checked for robustness.

By addressing these shortcomings, this article aims to shed light on the relative importance and variability of the country-of-origin impact on ER approaches in US subsidiaries as well as to identify the wider and more general lessons that can be drawn in the investigation of crossborder ER transfer issues. The study is based on a representative survey of US-owned and indigenous firms in the UK. This is the first representative quantitative study investigating the interrelationship between the country-of-origin effect on ER approaches in MNC subsidiaries and the level and type of industry internationalisation. The empirical investigation follows a two-pronged approach. First, a comparative analysis of US- and UK-owned firms is conducted to ascertain the average nationality effect in order to obtain a general picture of any differences that may arise as a result of variation in ownership nationality. Second, an 'intra-US' analysis is performed to explore possible variations in ER patterns among US subsidiaries along crucial industry dimensions. This is done in order to discern the possible differential impact of the country-of-origin effect in terms of its strength and nature between different industries.

\section{Employee relations in multinational companies}

Within the broadly institutional approach to ER in MNCs, a range of influences has been identified. A useful framework for the analysis of the relative influence of the country-of-origin effect is Edwards and Ferner's (2002) 'four forces' model. In this model, which draws upon arguments put forward within the new institutionalist literature, ER approaches in overseas 
subsidiaries are influenced by the complex interplay between home- and host-country effects, dominance effects and organisational effects arising from pressures for international integration. These effects result from the constraints that institutional frameworks place upon firms as well as the opportunities that those structures create for companies. The model highlights a number of important issues in the analysis of the cross-border transfer of ER approaches in MNCs. Importantly, the country-of-origin impact is not tout court, but a matter of degree. Indeed, none of the four influences is fully deterministic. As in other recent analyses that draw largely, but not exclusively, on institutional theories (Crouch 2005; North 2005), the model leaves room for the influence of agency and micro-political processes (Edwards, Colling and Ferner 2004). These latter factors are, however, beyond the scope of cross-sectional survey-based studies.

Drawing upon a mixture of sociological and rational-choice institutionalism, the four forces model connects the country-of-origin effect to the embeddedness of MNCs in their homecountry BS, including the IR sub-system. Such national institutional frameworks are said to shape MNC behaviour, including the way MNCs manage their international activities, such as ER issues (Ferner 1997). The US BS exhibits a deregulated and lightly institutionalised IR setting, dominated by an individualistic management philosophy and a deeply rooted management preference for non-union ER policies (Hall and Soskice 2001; Müller-Camen et al. 2004). Although a significant minority of US parent companies have conceded union recognition and collective bargaining, this is often due to legal necessity rather than choice. It, thus, masks an underlying and relatively widespread individualistic ER philosophy in the unionised sector (Ferner 2003). A relatively large section of US MNCs in the non-union sector operates with a 'high road' ER approach based on comprehensive, HRM-style direct employee involvement schemes, so-called 'high-involvement systems' (HIS) (Doeringe, Lorenz and Terkla 2003; Ferner 2003). This entails union substitution by emphasising comprehensive direct voice instead of collective voice. However, HISs are also at the heart of the wider and more elaborate 'high performance work systems' strand of the unitaristic US HRM literature and are, thus, often connected to notions of employee commitment, longer-term employment relationships, and extensive direct participation and consultation (Appelbaum, Bailey, Berg and Kallenberg 2000). The 'low road' cost-minimising numerical labour flexibility variant of the individualistic US model with few, if any, direct involvement practices is also not uncommon (Osterman 2002).

Although the individualistic 'high road' variant is frequently portrayed as the stereotypical ER approach of US MNCs, this downplays the variety of ER patterns that are possible in the US BS (Katz and Darbishire 2000; Jacoby 2005; Morgan 2005). Despite this, studies have consistently shown a strong home-country imprint among US MNCs compared to those from other countries or compared to indigenous firms on a number of crucial dimensions, such as organisational structure, decision-making and organisational control mechanisms (Child, Faulkner and Pitkethly 2001; Harzing and Sorge 2003; Carr 2005). The average US MNC tends to be relatively centralised with a high level of parental control and formalised management systems. This should facilitate the transfer of corporate-driven policies of non-union preferences and a marked diffusion of individualistic 'high road' ER patterns across US MNCs' international operations.

The dominance effect is connected to the performance hierarchy of economies (Smith and Meiskins 1995). Those in a dominant position evolve production methods and approaches to business, management and the organisation of work that are viewed in other countries as the best practices to adopt, and, hence, induce emulation in other countries. In the contemporary context, the perception of these 'global best practices' arise as a result of, first, the competitive advantages associated with the business and ER models of leading US MNCs, and, second, the strong economic record of the US, which occupies a dominant position in the international economy. In the ER spheres, such global best practice is frequently connected with the 
individualistic 'high road' approach, not least because of the supposed performance advantages attributed to this model (Chen, Lawler and Bae 2005). In order to gain these advantages, companies in non-dominant BSs may imitate aspects of this approach. The more widely such ER innovations are diffused among indigenous firms, the more difficult it may become to identify a distinctive US approach, even if this was once readily discernable. On the other hand, the dominance effect may reinforce (and subsume) the country-of-origin effect in US subsidiaries, as there may be strong incentives for US MNCs to transfer ER approaches which may have contributed to their competitive advantage. This should be visible in a fairly widespread diffusion of the 'high road' variant of the US ER model.

The extent to which the country-of-origin and dominance effects shape ER approaches in MNCs' subsidiaries is also influenced by the nature of the IR context in the host-country BS. The deregulated character of the UK BS resembles, in many respects, that of the US (Hall and Soskice 2001), despite a number of important differences. It provides great latitude for MNCs in the design of subsidiary ER approaches. The country-of-origin imprint in US-owned subsidiaries should be most visible in such a host-country context. In this connection, evidence suggests, first, that, although ER approaches in the UK's private sector are dominated by individualistic ER patterns, the unionised sector in the UK is still larger than that of the US, second, that individualistic HIS-based approaches remain relatively rare compared to the US and, finally, that individualistic 'low road' approaches are a comparatively common feature of ER in UK firms (WERS 2004).

The degree to which MNCs are subject to competitive pressures to integrate their international operations shapes the relative strength of the home-country and dominance effects in their subsidiaries. Pressures for international integration arise from the imperative for effective international operation, which, in turn, encourages a high degree of co-ordination and integration of cross-border activity and the international division of labour within the MNC. This creates incentives to develop common policies and approaches, including those in the ER area, across international operations. In turn, this provides greater scope for the home-country and/or dominance effect to exert an influence. However, competitive pressures for international integration do not constitute a universal force; they are, to a considerable extent, contingent upon the nature of the industry and, in particular, upon the degree of its global exposure (Dunning 2000; see also, Jacoby 2005 for more on cross-national policy convergence within industries).

MNCs operating in an industry with a relatively low degree of industry internationalisation face higher pressures for local responsiveness or isomorphism and lower pressures for the international integration of activities. This, in turn, suggests a relatively muted country-of-origin imprint on subsidiary ER and a greater emphasis on locally flavoured ER approaches. However, as noted above, US MNCs are characterised by a comparatively high degree of centralisation and parental control. This country-of-origin trait may entail a relatively stronger home-country imprint in subsidiary ER patterns even in less internationalised industries compared to subsidiaries of MNCs from other countries. However, compared to their US-owned counterparts in highly internationalised industries, the strength of the host-country effect in US subsidiaries in less internationalised industries can be expected to be relatively stronger and the home-country effect to be, consequently, relatively less pronounced.

Pressures for international integration are, however, particularly pertinent in highly internationalised industries. Thus, corporate-driven non-union policies may be more pronounced at the subsidiary level among US MNCs that operate in highly internationalised industries than they are in those in less internationalised industries. Furthermore, in such industries, global competitive pressures are frequently assumed to create pressures for convergence in MNCs' policies around a global best-practice template (Strange 1997). Despite the popular stereotyping of the ER 'high road' variant of the US model as the best-practice approach, even in highly 
internationalised industries the notion of best practice has no universal currency, but has an industry-specific configuration that reflects, inter alia, differences in labour markets, humancapital, knowledge and technology intensity. A host of studies has highlighted the differential impact of industry differences along these dimensions on international business activities (Dunning and Lundan 1998; Katz and Darbishire 2000; Jacoby 2005; Pak and Park 2005).

ER in US MNCs in industries that are more technology, knowledge and human-capital intensive, and that are more reliant on a stable and skilled workforce may be more likely to resemble the 'high road' approach. In more labour-intensive and low-technology industries, such an approach is less viable and the ER patterns may be more likely to entail the use of numerical labour flexibility based on a cost-minimising approach. Thus, within the permissive UK host-country context, considerable variation in the nature of the cross-border transfer of US ER patterns can be expected even in highly internationalised industries. The individualistic 'high road' approach can be expected to be prevalent in subsidiaries that operate in more skills-intensive industries (using skills intensity as proxy for the highly correlated concepts of technology, knowledge and human capital intensity), whereas those in less skills-intensive industries may be expected to pursue the individualistic 'low road' approach. However, the effect of the level and type of industry internationalisation does not work in isolation, but interacts with the other key influences in a complex way to shape ER patterns in overseas subsidiaries.

Definitive conclusions cannot be drawn on these matters from the empirical evidence on ER transfer issues in US-owned subsidiaries in the UK, and elsewhere. The available qualitative studies, though providing rich, detailed insights, cannot be easily generalised. The findings of quantitative studies are not directly comparable, partly because of the limitations outlined above. In light of these limitations, the general tenor of quantitative studies seems to confirm only partially the conventional stereotype of the US approach. Even studies of US subsidiaries in economies with similar IR contexts tend to show that there is only limited support for the implementation of corporate-driven non-union policies at the subsidiary level, as the nationality differences between US and indigenous firms are either only weakly significant (Guest and Hoque 1996; Walsh 2001) or non-significant (Turner, D’Art and Gunnigle 1997; Geary and Roche 2001).

However, survey-based evidence with regard to direct employee involvement practices is generally more supportive (Child et al. 2001; Geary and Roche 2001; Schmitt and Sadowski 2003; Chen et al. 2005). Furthermore, evidence from qualitative studies highlights a prevalent, though not universal, pursuit of the individualistic 'high road' approach (e.g. Geppert et al. 2003). Although quantitative studies tend not to investigate explicitly the variability of the strength and nature of the country-of-origin effect in international operations of US MNCs across different industry subsets, some case-study evidence does, nevertheless, seem to corroborate the differential ER outcomes proposed above that arise from the interplay between country-of-origin and industry-specific effects (Marginson, Hall, Hoffman and Muller 2004; Müller-Camen et al. 2004). Furthermore, a recent survey-based study of German subsidiaries in the UK, though employing only a uni-dimensional industry categorisation, highlights significant variations in ER patterns amongst German subsidiaries along the degree of industry internationalisation (Tüselmann et al. 2006).

This discussion leads to two hypotheses. The first relates to the average country-of-origin effect in UK-based subsidiaries of US MNCs, and the second relates to the variability, in terms of its strength and nature, of the country-of-origin effect among US subsidiaries.

Hypothesis 1: ER approaches in UK-based subsidiaries of US MNCs exhibit a distinctive country-of-origin effect, with US subsidiaries being less likely to exhibit a tradeunion approach and more likely to pursue an individualistic 'high road' approach while being less likely to deploy a 'low road' approach compared to indigenous UK firms. 
Hypothesis 2: US subsidiaries in highly internationalised industries are less likely to have a union-based ER approach relative to those in less internationalised industries, with subsidiaries in skills-intensive, highly internationalised industries being more likely to emphasise the individualistic 'high road' ER approach and those in less skills-intensive, but highly internationalised industries being more likely to employ a 'low road' ER approach.

\section{Data and methodology}

The study is based on a representative survey of US subsidiaries in the UK and private-sector UK-owned multi-establishment firms with at least 25 employees. The data were collected in 2004 using a pre-tested structured questionnaire that was sent to the managing directors of the sampled firms. The sampling frames were constructed from a range of sources, such as Chambers of Commerce, regional development authorities and the Dun and Bradstreet List. A stratified random sampling method was used to obtain representative samples according to size and industry stratification criteria. Two representative samples of 900 establishments for each nationality were drawn. This sampling design ensured that the sufficiency requirements for multivariate data analysis were met (Long 1997) for the pooled sample of UK- and US-owned establishments. In short, the research was designed to ensure that sufficiently high response rates from both nationality groups were obtained in order to avoid potential bias in the regression analyses, which can result from heavily skewed nationality groups, while also employing, at the same time, the conventional size/industry stratification criterion. The response rates were 20.7 and $33.2 \%$ for US- and UK-owned establishments, respectively. The response rate for the combined samples was $27.0 \%$; this compares well with similar survey-based studies (e.g. Guest and Hoque 1996; Doeringer, Lorenz and Terkla 2003; Chen et al. 2005). Standard checks for representativeness, such as z tests and $\chi^{2}$ tests, for both nationality samples proved satisfactory and tests for non-response bias for both nationality samples suggested that the study's empirical work is not influenced by non-response bias.

Three broad ER approaches were defined: the trade-union approach, the individualistic 'high road' approach and the individualistic 'low road' approach. These broad classifications inevitably understate the variety within each approach; yet they serve to focus attention on key ER policy choices and on the overall ER orientation. The ER approaches were defined by using dichotomous measures. The trade-union approach was defined in terms of trade-union recognition and the associated presence of workplace union representation. Non-union establishments that have developed HISs were defined as pursuing an individualistic 'high road' ER approach and those without a HIS as having an individualistic 'low road' ER approach.

In the absence of a commonly agreed definition, list of practices and measurement approach, a broad working definition for HISs was adopted. Following Cappelli and Neumark (2001), this entailed an assessment of direct participation, consultation and information-sharing schemes. The list of practices was constructed from a series of items that are consistent with the theoretical and empirical research. These items include: partly autonomous teamwork; quality circles/problem-solving groups; attitude surveys; suggestion schemes; regular meetings; team briefings; newsletters; and the systematic use of the management chain. A weighted composite index was constructed on the basis of the incidence of these practices and the differential degree of employee involvement connected with these practices. In order to determine which of the respondents had a HIS in place, the mean of the composite index was calculated. Those respondents above the mean were defined as having a HIS. To verify the suitability of the weighting scheme that was used, sensitivity analysis using alternative scoring systems produced similar results. The Crohnbach's alpha reliability coefficient for the HIS construct was 0.71 , which falls within the acceptable value range. 
The level of internationalization of industries was measured along the lines of the UNCTAD Transnationality Index (UNCTAD 2006). This index is compiled using the ratio of foreign to total sales, the ratio of foreign to total employment and the ratio of outward FDI to gross fixed capital formation. On this basis, an internationalization index was calculated as the average of these three ratios for each industry at the NACE Division level. From this, the average for all industries was calculated. Industries above the index average were categorized as highly internationalized. The skills intensity of industries was ascertained with reference to the ILO International Standard Classification of Occupations (ISCO) and the ISCO Skill Level definition (ILO 1997). Industries with an above-average share of highly and intermediate skilled employees were defined as skills intensive. On this basis, highly internationalized industries were further differentiated as either skills or less skills intensive.

The ER approaches were treated as dependent variables. Given their dichotomous nature, the hypotheses were tested by logistic regression models (Agresti 2001). Besides the explanatory variables of interest, a range of additional variables, based on the findings of relevant previous studies (Schmitt and Sadowski 2003; Chen et al. 2005) was included in the regression estimates as control variables (see the Notes under the tables). In order to avoid the potential violation of the assumption of a linear relationship between continuous predicators and the logit transformation of the dependent variable, all continuous variables were transformed into categorical variables. Relevant likelihood ratio tests in relation to omitted variables and for data pooling raised no concerns. Checks for collinearity between the independent variables indicated no multicollinearity problems. Additionally, the robustness of the logistic regression calculations was tested by moderately altering the set of control variables and by running probit instead of logistic regressions. The regression results concerning the explanatory variables of interest are robust.

\section{Empirical findings and discussion}

The results of the regression estimates for the pooled sample and the US sample are presented in Table 1 and Table 2, respectively. The results in these tables show the extent to which the explanatory variables of interest, i.e. nationality of ownership in the pooled sample and type of industry in the US sample analysis, are significant after allowing for the influence of the control variables. Overall, the empirical models perform well. All model $\chi^{2} s$ are significant at either the 1 or $5 \%$ levels. Thus, all the regressions are meaningful models. The relatively high values for the pseudo $\mathrm{R}^{2} \mathrm{~s}$ (with the possible exception of the second model in Table 1) are another indication of the quality of the regression models. The pseudo $\mathrm{R}^{2}$ values are, overall, quite

Table 1. Nationality-of-ownership differences in employee relations approaches.

\begin{tabular}{lcccccc}
\hline & \multicolumn{3}{c}{ Mean } & & \\
\cline { 2 - 3 } Dependent variable & $U K$ & $U S$ & $\begin{array}{l}\text { Coefficient } \\
\text { (standard error in brackets) }\end{array}$ & Model $\chi^{2}$ & $R^{2}$ \\
\hline Trade-union approach & .33 & .26 & $-.582(.302) *$ & 98.951 & .308 \\
Individualistic 'high road' approach & .29 & .51 & $1.175(.378) * * *$ & 64.243 & .188 \\
Individualistic 'low road' approach & .38 & .22 & $-.486(222) * *$ & 78.701 & .286 \\
\hline
\end{tabular}

Notes: 1) Logistic regressions. $\mathrm{R}^{2}$ is pseudo; 2) Number of observations: 485 ; 3 ) Coefficients are $1-0$ variable: 1 is for US-owned and 0 is for UK-owned firms; 4) Controls: establishment size (5 categories), industry (based on NACE classification at Division level, collapsed into 7 categories), region (based on Government Official Region classification, collapsed into 4 categories), share of skilled labour (based on ILO classification system, 4 categories), share of part-time workers (3 categories), whether greenfield site, whether main market abroad, establishment age (5 categories); 5 ) *significant at the $10 \%$ level, **significant at the 5\% level, ***significant at the $1 \%$ level. 
Table 2. Industry internationalization characteristics and employee relations approaches in US subsidiaries.

\begin{tabular}{|c|c|c|c|c|c|c|c|}
\hline \multirow[b]{2}{*}{ Dependent variable } & \multicolumn{3}{|c|}{ Mean } & \multicolumn{2}{|c|}{$\begin{array}{l}\text { Coefficient (standard error } \\
\text { in brackets) }\end{array}$} & \multirow[b]{2}{*}{ Model $\chi^{2}$} & \multirow[b]{2}{*}{$R^{2}$} \\
\hline & $L I I$ & HISII & HILSII & HISII & HILSII & & \\
\hline Trade-union approach & .39 & .14 & .17 & $-.845(.255) * * *$ & $-.920(.294) * * *$ & 74.209 & .382 \\
\hline $\begin{array}{l}\text { Individualistic } \\
\text { 'high road' approach }\end{array}$ & .37 & .72 & .33 & $1.319(.508) * * *$ & $-.270(.484)$ & 62.015 & .264 \\
\hline $\begin{array}{l}\text { Individualistic } \\
\text { 'low road' approach }\end{array}$ & .23 & .15 & .51 & $-.449(316)$ & $.615(.275) * *$ & 39.982 & .317 \\
\hline
\end{tabular}

Notes: 1 ) LII = less internationalized industry, HISII $=$ highly internationalized, skills-intensive industry, HILSII $=$ highly internationalized, less skills-intensive industry; 2) See Notes (i), (iv) and (v) under Table 1;3) Number of observations: 186; 4) Coefficients are for type of industry. The reference group is less internationalised industries (LII).

respectable for logistic models and are, in part, even higher than those in comparable studies (Guest and Hoque 1996; Walsh 2001; Chen et al. 2005).

\section{Comparative analysis of US- and UK-owned firms}

Overall, the results in Table 1 seem to support a country-of-origin effect as proposed in hypothesis 1 . However, with regard to the union approach, the evidence to support the transfer of distinct, corporate-driven non-union policies that reflect the prevailing individualistic ER philosophy of the US model is weak. US subsidiaries are less likely - in only a weakly significantly way - to exhibit union-based ER approaches compared to UK firms. This finding is in line with previous studies of US MNCs' operations in Anglo-Saxon IR contexts (see above). As a first approximation, this result may indicate that, despite a recognizable degree of 'Americaness' in the collective labour relations of US MNCs in the UK, this is combined, to a considerable degree, with a host-country effect. This interplay produces, on average, a modest net country-of-origin imprint. Several partial explanations may, in combination, explain the apparently modest strength of the home-country effect.

The demise of the pluralist union-based collective workplace IR system, which can mainly be attributed to the IR and wider economic reform policies of the Conservative governments in the 1980s and 1990s, encouraged employers to move from collective to individualised labour relations (Poole, Lansbury and Wailes 2001; Zagelmeyer 2003). This led to a drastic decline in union recognition. Thus, to a certain extent, the weakly significant nationality differences in union recognition currently observed might be attributable to developments in the UK IR landscape over the last few decades. Therefore, the non-union approach in the UK-based subsidiaries of US MNCs becomes less readily identifiable as a distinct country-of-origin trait. Several case-study findings (Müller-Camen et al. 2004; Colling and Clark 2006) suggest that this result may also partly reflect the pragmatic adoption of prevailing local practices among a certain subset of US subsidiaries in situations of significant pressures for mimetic isomorphism due, inter alia, to local responsiveness and legitimacy reasons. Moreover, the incidence of a trade-union approach among US subsidiaries may partly reflect pre-existing collective ER arrangements in, for example, the case of acquisitions. In such instances, it may be difficult and costly to change existing ER systems. Thus, the incidence of union recognition may mask the extent of underlying individualistic ER preferences. Moreover, the diversity in home-country ER patterns among US MNCs implies that unionisation in some of the subsidiaries may be accounted for by MNCs in which the parent firm recognises a union in the US and in which the parent-company ER model serves as the template for the corporate-wide policy approach. 
With regard to the individualistic 'high road' and 'low road' approach, there is strong support for the country-of-origin effect as proposed in hypothesis 1 . The greater propensity, which is highly significant, of US subsidiaries to pursue the non-union route with a 'high road' ER model compared to their UK-owned counterparts seems to support the expectation that the dominance effect reinforces the country-of-origin effect in the international operations of US MNCs and that it is those, in particular, that are located in deregulated host-country IR contexts that are the visible bearers of the popular, stereotypical best-practice approach. The findings also, however, indicate that the dominance effect has not spurred on the widespread diffusion of ER innovations in indigenous UK firms: less than $30 \%$ of UK firms have adopted the individualistic HIS-based 'high road' approach. Corroborating the results of other studies (see above), the findings seem to suggest that US MNCs are the front runners in the deployment of the innovative variant of the individualistic ER model in host countries. However, the transfer of this approach is evident in only approximately one-half of the US subsidiaries. It appears, therefore, that, despite the great latitude provided by the UK's IR context, non-union 'high road' ER patterns are a distinctive, but not a universal, feature among the cross-section of US firms in the UK. Although the individualistic 'high road' approach is strongly associated with US subsidiaries, the magnitude of the dissemination of this approach among US subsidiaries cautions against the popular stereotyping of ER in international sites of US MNCs. This result underlines the need to appreciate the variety of ER patterns exhibited by US MNCs within their home-country BS.

As expected, US subsidiaries are significantly less likely to deploy the non-union 'low road' variant compared to indigenous UK establishments. Nevertheless, over one-fifth of US subsidiaries deploy this ER approach. Thus, the country-of-origin effect - in the form of a lower incidence of the 'low road' approach among the cross-section of US subsidiaries compared to UK-owned firms - may obscure important differences in subsections of US subsidiaries. In view of the relatively widespread use of the cost-minimizing labour flexibility route of the individualistic approach among UK firms, this approach by US subsidiaries may, in part, constitute the adoption of prevailing local practices among a subset of US subsidiaries that face strong pressures within their business environment for local isomorphism. The incidence of the 'low road' approach among US subsidiaries may also, in part, constitute a transfer of the homecountry ER model by those US parent companies that operate such an approach in the US. This discussion suggests that the average US home-country effect revealed in the comparative nationality analysis may conceal important variations in its relative strength and nature within the cross-section of US subsidiaries. An analysis of the level and type of industry internationalization is required to help shed light on these issues.

\section{Intra-US analysis: industry characteristics and variations in employee relations approaches}

The findings in Table 2 confirm the postulated differential impact of the level and type of industry internationalization on the ER patterns in UK-based US subsidiaries in hypothesis 2. The results confirm and extend the insights of a number of case studies that highlight, first, an attenuation of the country-of-origin effects stemming from various industry-specific traits (Marginson et al. 2004), second, a shifting balance between the net impact of the interaction between home- and host-country effects depending on the US subsidiary's industry (Colling and Clark 2006; Geppert et al. 2003), and, finally, the differential nature of the country-of-origin effect revealed in qualitative multi-industry studies of US subsidiaries (Müller-Camen et al. 2004).

As hypothesized, subsidiaries of US MNCs that operate in highly internationalized industries are significantly less likely to be unionized than those in less internationalized industries. The evidence, thus, suggests that the level of internationalization has significant 
effects on ER approaches in US subsidiaries. This sheds a different light on the average nationality effect obtained in the preceding section and supports the view that the weakly significant difference compared to indigenous UK-owned firms may, at least partly, mask variations among US subsidiaries in terms of differential pressures for international integration. Corporate-driven non-union ER policies seem to be a defining feature of US MNCs in highly internationalized industries where stronger pressures for international integration prevail. Here, the net outcome of the interaction between home-country, host-country and industry effects seems to entail a relatively strong home-country effect in the form of a widespread transfer of individualistic ER templates to US MNCs' UK subsidiaries.

Conversely, the findings provide some support for the assertion that, despite a high level of centralized parental control among US MNCs, in less internationalized industries, lower pressures for international integration and higher pressures for local responsiveness may make stronger locally flavoured ER strategies more viable. In this case, the net outcome of the interplay between home-country, host-country and industry effects may be a relatively weaker country-of-origin and relatively stronger host-country imprint. Some case-study evidence of UK-based US subsidiaries in such an industry context also lends support to this ER outcome (Colling and Clark 2006).

The findings strongly support the proposition in hypothesis 2 that the pervasive country-oforigin effect in the form of union-avoidance strategies among subsidiaries of US MNCs in highly internationalised industries is connected to different varieties of the individualistic US model depending on the skills intensity of the industry. US subsidiaries in highly internationalized, skills intensive industries are more likely - in a highly significant way - to deploy the HISbased individualistic 'high road' ER approach compared to their counterparts in less internationalized industries, whereas US subsidiaries that operate in less skills-intensive, highly internationalized industries have a highly significant greater propensity to deploy the 'low road' ER approach. The results, therefore, provide evidence that the type of industry internationalization has a marked effect on the ER approaches in US subsidiaries.

The findings show that the popular, stereotypical US ER approach in the international arena is very much a feature of US-owned firms in skills-intensive industries with a high degree of global exposure. Of those UK-based US subsidiaries in such a setting, over $70 \%$ adopt the individualistic 'high road' approach to ER. In this type of industry, comprehensive employee voice and participation systems, which may take the form of direct HISs, are part and parcel of a productivity-orientated competitive strategy. Conversely, the more commonly deployed 'low road' ER approach amongst US subsidiaries in less skills-intensive, highly internationalized industries may imply the prevalence of international strategies that are based on lowering costs in this type of industry. The results of the 'intra-US' analysis underline the variety in both the strength and nature of the country-of-origin effect in the transfer of ER approaches among US subsidiaries which emerge from the interface of differential industry internationalization effects with home- and host-country effects. These insights were masked in the comparative analysis with indigenous UK firms, which only ascertained the average nationality effect.

Careful reading of the results in Table 2, however, lends greater credence to the popular, stereotypical US approach regardless of industry characteristics: over one third of US subsidiaries in both less internationalized industries, on the one hand, and less skill-intensive, highly internationalized industries, on the other, operate with an individualistic 'high road' ER approach. This implies that the relative strength of pressures arising from the nature of the industry in shaping subsidiary ER outcomes is far more nuanced even within the same industry context. Therefore, even if approximately one half of the US subsidiaries in less skills-intensive, highly internationalized industries operating with 'low road' ER patterns, this approach should be seen as a common, but not a universal, feature among such subsidiaries. The level of co-existence of both 
variants of the individualistic US model (the 'high road' and the 'low road') even within the same broad industry context could indicate that there might be segments within this type of industry where the 'high road' approach is a viable alternative. However, shedding more light on such issues is beyond the scope of this study since the sample size does not allow for further industry differentiation without compromising the statistical rigour of the multivariate regression analysis.

\section{Conclusions}

This study has enhanced our understanding of the country-of-origin effect in international operations of US MNCs. It has confirmed a number of insights that have been revealed in case studies of US MNCs in the UK (and elsewhere) and has extended previous survey-based work by providing a richer and more nuanced picture than conventionally obtained from many quantitative studies. By including important industry internationalization characteristics not only along the dimension of the level of industry internationalization, but also in terms of human-capital, technology and knowledge intensity (subsumed within the measure of skills intensity), this study has shed new light, first, on the interplay between home-country effects, which in the case of US MNCs subsume dominance effects, and host-country effects and, second, on the impact of industry characteristics in shaping the relative strength and nature of the country-of-origin effect in US subsidiaries in the UK. The design and representative nature of this study allow the results to be generalized to a relatively high degree.

The comparative cross-sectional analysis of US subsidiaries and indigenous UK firms confirmed the general tenor of previous studies on US subsidiaries in Anglo-Saxon host-country IR contexts of a distinct US country-of-origin ER imprint. Such subsidiaries are somewhat less likely to follow a trade-union approach, are substantially more inclined to operate with the so-called best-practice approach (an individualistic HIS-based 'high road') and are less likely to deploy a cost-minimizing numerical labour flexibility-flavoured 'low road' approach compared with UK-owned firms. However, the weaker than expected evidence for the transfer of corporate-driven non-union policies, the common, but not universal, development of the individualistic 'high road' approach and the 'non-negligible' incidence of the 'low road' approach among US subsidiaries highlight the need for a more reflective interpretation of nationality differences. The magnitude of the various ER approaches among the US subsidiaries can, at least in part, be accounted for by some combination of, inter alia, the variety and diversity of ER patterns among parent companies in the US BS, the differential pressures for local isomorphism, and developments in the host-country IR landscape over the past decades.

The detailed analysis of ER approaches revealed significant variations according to important industry characteristics. The intra-US analysis highlighted the mediating, as well as the differential, role of both the level and the type of industry internationalization in shaping the strength and nature of the country-of-origin effect. Non-union ER approaches are a defining feature of subsidiaries of US MNCs that operate in highly internationalized industries. Thus, a strong country-of-origin effect in the form of the widespread use of non-union approaches in US MNCs abroad is not a universal attribute of such subsidiaries, but is very much a defining feature of ones in industries that face competitive pressures for the international integration of MNC activity.

However, the dominance of individualistic ER templates among this type of subsidiary takes a different form according to the skills intensity of industries and, hence, the competitive focus this implies. Whereas the 'high road' approach is a defining feature of subsidiaries in highly internationalised, skills-intensive industries, the 'low road' approach is relatively common in highly internationalised, less skills-intensive industries. Thus, the conventional perception of the individualistic 'high road' ER approach of US MNCs abroad is not a universal feature of such subsidiaries, but is only a highly common characteristic in a particular subset of subsidiaries. 
Indeed, the findings of this study underscore that it might be more appropriate to speak of 'industry best practice' rather than 'global best practice'. Despite this, the evidence also lends some weight to the stereotypical view of ER in US MNCs abroad (i.e. the individualistic 'high road' variant) regardless of these industry characteristics. Such a finding underlines the fact that the relative strength of industry pressures in the interplay between home- and host-country effects is highly nuanced even within the same broad industry context. This underpins the contention of the 'four influences' model that none of these forces is deterministic, but is a matter of degree.

A number of lessons can be drawn from the above for the analysis of cross-border ER transfer issues in MNCs. In particular, survey-based studies need to pay greater attention to the diversity and variety of ER approaches in both home- and host-country BSs, as well as to locating empirical findings within the context of developments within IR systems. Moreover, a greater level of intricacy is required in the interpretation of the statistical results by appreciating that the countryof-origin effect is not absolute but a matter of degree, with the outcome being shaped by the complex interplay between various influences. Moreover, survey-based studies need to pursue a greater level of complexity by treating the relative importance of crucial industry characteristics in a more explicit way, thereby allowing for a variety of home country-influenced ER outcomes, both in terms of strength and nature. The conventional approach employed in most of these studies depicts the general picture of ER in international subsidiaries; however, the analysis is halted too early. Furthermore, in addressing the interplay of industry effects in shaping ER outcomes in subsidiaries, studies have to go beyond the popular, but uni-dimensional, use of the degree of global exposure of industries and the attendant pressures for international integration, by including other important industry attributes. This could help to explain the different ER outcomes among subsidiaries of the same nationality, even in highly internationalized industries.

To shed more light on the issues addressed in this study, similar representative studies of US subsidiaries in other major host locations of US FDI are required. Studies of US subsidiaries in host IR contexts such as Germany or Japan may be particularly fruitful, as these will enable analyses of the ways in which the interactions between home-country, host-country and industry internationalisation effects play out in more densely institutionalised and regulated IR contexts. Moreover, comparative studies of US subsidiaries with those of MNCs from other major FDI source countries, such as Japan, across a range of industries along the lines of this study are required. Such comparisons, especially those with subsidiaries of MNCs from non-dominant BSs, can provide an important contribution to the wider convergence/divergence debate on ER patterns across MNCs, in general, and, in particular, on the notions of clustered divergences and convergences (Harzing and Sorge 2003).

\section{Acknowledgement}

The article is based on a research project on employee relations and firm performance of foreign-owned subsidiaries in the UK, funded by the Hans Böckler Foundation, Germany.

\section{References}

Agresti, A. (2001), Categorical Data Analysis, New York: John Wiley.

Appelbaum, E., Bailey, T., Berg, P., and Kallenberg, A. (2000), Manufacturing Advantage - Why High Performance Work Systems Pay Off, Ithaca, NY: ILR Press.

Cappelli, P., and Neumark, D. (2001), 'Do "High Performance" Work Practices Improve Establishmentlevel Outcomes?' Industrial and Labor Relations Review, 54, 4, 737-775.

Carr, C. (2005), 'Are German, Japanese and Anglo-Saxon Strategic Decision Styles still Divergent in the Context of Globalization?' Journal of Management Studies, 42, 6, 1155-1178.

Chen, S., Lawler, J., and Bae, J. (2005), 'Convergence in Human Resource Systems: a Comparison of Locally Owned and MNC Subsidiaries in Taiwan,' Human Resource Management, 44, 3, 237-256. 
Child, J., Faulkner, D., and Pitkethly, R. (2001), The Management of International Acquisitions, Oxford: Oxford University Press.

Clark, I., and Almond, P. (2004), 'Dynamism and Embeddedness: Towards a Lower Road? British Subsidiaries of American Multinationals,' Industrial Relations Journal, 35, 6, 537-556.

Colling, T., and Clark, A. (2006), 'What Happened when the Americans Took Over Britain's Electricity Industry? Exploring Trans-national Sector Effects on Employment Relations,' International Journal of Human Resource Management, 17, 9, 1625-1644.

Crouch, C. (2005), Capitalist Diversity and Change: Recombinant Governance and Institutional Entrepreneurs, Oxford: Oxford University Press.

Doeringer, P., Lorenz, E., and Terkla, D. (2003), 'The Adoption and Diffusion of High-performance Management: Lessons from Japanese Multinationals in the West,' Cambridge Journal of Economics, $27,2,265-286$.

Dunning, J. (2000), 'The Eclectic Paradigm as an Envelope for Economic and Business Theories of MNE Activity,' International Business Review, 9, 163-190.

Dunning, J., and Lundan, S. (1998), 'The Geographical Sources of Competitiveness of Multinational Enterprises: an Econometric Analysis,' International Business Review, 7, 2, 115-133.

Edwards, T., Colling, T., and Ferner, A. (2004), 'Comparative Institutional Analysis and the Diffusion of Employment Practices in Multinational Companies,' IESE Conference, Barcelona, 14-17 July.

Edwards, T., and Ferner, A. (2002), 'The Renewed "American Challenge": A Review of Employment Practices in US Multinationals,' Industrial Relations Journal, 33, 2, 94-111.

Edwards, T., and Kuruvilla, S. (2005), 'International HRM: National Business Systems, Organizational Politics and the International Division of Labour,' International Journal of Human Resource Management, 16, 1, 1-25.

Ferner, A. (1997), 'Country of Origin Effects and Human Resource Management in Multinational Companies,' Human Resource Management Journal, 7, 1, 19-37.

Ferner, A. (2003), 'Foreign Multinationals and Industrial Relations Innovations in Britain,' in Industrial Relations: Theory and Practice (2nd ed.), ed. P. Edwards, Oxford: Blackwell, pp. 81-104.

Ferner, A., Almond, P., Clark, I., Colling, T., and Holden, L. (2004), 'The Dynamics of Central Control and Subsidiary Autonomy in the Management of Human Resources: Case Study Evidence from US MNCs in the UK,' Organization Studies, 25, 3, 363-391.

Ferner, A., Quintanilla, J., and Varul, M. (2001), 'Country-of-Origin Effects, Host Country Effects and the Management of HR in Multinationals: German Companies in Britain and Spain,' Journal of World Business, 36, 2, 107-127.

Geary, J., and Roche, W. (2001), 'Multinationals and Human Resource Practices in Ireland: A Rejection of the New Conformance Thesis,' International Journal of Human Resource Management, 12, 1, $109-127$.

Geppert, M., Matten, D., and Williams, K. (2003), 'Change Management in MNCs: How Global Convergence Intertwines with National Diversity,' Human Relations, 56, 7, 807-838.

Guest, D., and Hoque, K. (1996), 'National Ownership and HR Practices in UK Greenfield Sites,' Human Resource Management Journal, 6, 4, 50-74.

Hall, P., and Soskice, D. (eds.) (2001), Varieties of Capitalism: The Institutional Foundations of Comparative Advantage, Oxford: Oxford University Press.

Harzing, A., and Sorge, A. (2003), 'The Relative Impact of Country-of-Origin and Universal Contingencies on Internationalization Strategies and Corporate Control in Multinational Enterprises: Worldwide and European Perspectives,' Organization Studies, 24, 2, 187-221.

ILO (International Labour Organization) (1997), Occupational Classification: Concepts, Methods, Reliability, Validity and Cross-national Comparability, Geneva: ILO.

Jacoby, S.M. (2005), The Embedded Corporation: Corporate Governance and Employment Relations in Japan and the United States, Princeton, NJ: Princeton University Press.

Katz, H., and Darbishire, O. (2000), Converging Divergences: Worldwide Changes in Employment Systems, Ithaca, NY and London: Cornell University Press.

Long, J. (1997), Regression Models for Limited Dependent Variables, London: Sage.

Marginson, P., Armstrong, P., Edward, P., and Purcell, J. (1995), 'Extending beyond Borders: Multinationals Companies and the International Management of Labour,' International Journal of Human Resource Management, 6, 3, 702-719.

Marginson, P., Hall, M., Hoffmann, A., and Muller, T. (2004), 'The Impact of European Works Councils on Management Decision Making in UK and US based Multinationals: A Case Study Comparison,' British Journal of Industrial Relations, 42, 2, 209-233. 
Morgan, G. (2005), 'Institutional Complementarities, Path Dependency and the Dynamics of Firms,' in Changing Capitalisms? eds. G. Morgan, R. Whitley and E. Moen, Oxford: Oxford University Press, pp. 415-446.

Müller-Camen, M., Tempel, A., Almond, P., Edwards, T., Ferner, A., Peters, R., and Wächter, H. (2004), 'Human Resource Management of US Multinationals in Germany and the UK,' Report for the AngloGerman Foundation for the Study of Industrial Society, September 2004, retrieved on 14 March 2007 from: http://www.agf.org.uk/pubs/pdfs/1292web.pdf

Nachum, L., and Zaher, S. (2005), 'The Persistence of Distance? The Impact of Technology on MNE Motivations for Foreign Investment,' Strategic Management Journal, 26, 747-767.

North, D.C. (2005), Understanding the Process of Economic Change, Princeton, NJ: Princeton University Press.

Osterman, P. (2002), 'Wandel in der Arbeitsorganisation in den USA,' WSI Mitteilungen, 55, 10, 586-592.

Pak, Y.-S., and Park, Y.-R. (2005), 'Characteristics of Japanese FDI in the East and the West: Understanding the Strategic Motives of Japanese Investment,' Journal of World Business, 40, 3, 254-266.

Poole, M., Lansbury, R., and Wailes, N. (2001), 'A Comparative Analysis of Developments in Industrial Democracy,' Industrial Relations, 40, 3, 490-525.

Scullion, H., and Starkey, K. (2000), 'In Search of the Changing Role of the Corporate Human Resource Function in the International Firm,' International Journal of Human Resource Management, 11, 6, $1061-1081$.

Schmitt, M., and Sadowski, D. (2003), 'A Cost-minimizing Approach to the International Transfer of HRM/IR Practices: Anglo-Saxon Multinationals in the Federal Republic of Germany,' International Journal of Human Resource Management, 14, 3, 409-430.

Smith, C., and Meiskins, P. (1995), 'System, Society and Dominance Effects in Cross-National Organizational Analysis,' Work, Employment and Society, 9, 2, 241-267.

Strange, S. (1997), 'The Future of Global Capitalism: Or Will Divergence Persist for Ever?' in Political Economy of Modern Capitalism, eds. C. Crouch and W. Streeck, London: Sage, pp. 182-191.

Turner, T., D'Art, C., and Gunnigle, P. (1997), 'Pluralism in Retreat? A Comparison of Irish and US Multinational Manufacturing Companies,' International Journal of Human Resource Management, $8,6,721-755$.

Tüselmann, H., McDonald, F., and Thorpe, R. (2006), 'The Emerging Approach to Employee Relations in German Overseas Affiliates: A Role Model for International Operation?' Journal of World Business, $48,1,66-80$.

UNCTAD (2006), World Investment Report 2006, New York and Geneva: United Nations.

Walsh, J. (2001), 'Human Resource Management in Foreign-owned Workplaces: Evidence from Australia,' International Journal of Human Resource Management, 12, 3, 425-444.

WERS (2004), Workplace Employee Relations Survey 2004, available from: http://qb.soc.surrey.ac.uk/ surveys/wers/wers04.htm

Zagelmeyer, S. (2003), 'Die Entwicklung kollektiver Verhandlungen in Großbritannien: Ein historischer Rückblick,' Industrielle Beziehungen, 10, 1, 118-144. 